\title{
Potensi Pasar Tradisional Simabur bagi Masyarakat di Nagari Simabur Kecamatan Pariangan Kabupaten Tanah Datar
}

\author{
Ahmad Mustafa \\ Program Studi Pendidikan Geografi STKIP PGRI Sumatera Barat \\ mustafaahmad@gmail.com
}

\begin{abstract}
This research conducted in kenagarian Simabur Pariangan districs Tanah Datar regency, which aims to determine the potential of tradisional market Simabur for people in villages Simabur Pariangan districs Tanah Datar regency both interms of jobs, household incomes and land lease. The type of the research belong to the descriptive study sampling taken technique Proporsional Random Sampling, with a sample of 73 people. The sample is peope there, merchants located around the Simabur market, collecting data though observation and direct observation from the field to the questionnaire.

This research resulted in several conclussions : (1) The potential market for employment in the village community in Simabur Pariangan districs Tanah Datar regency to work, on a general merchant, (2) The potential market for the income of the people in the Simabur village Pariangan districs Tanah Datar regency the average income of market than Rp.2.000.000, (3) Potential market for land lease communities in Simabur village Pariangan districs Tanah Datar regency the everage lease for every day is Rp.3000-6000.
\end{abstract}

Keywords : Potential, Market, Communities

\section{Abstrak}

Penelitian ini di lakukan di Kenagarian Simabur Kecamatan Pariangan Kabupaten Tanah Datar, yang bertujuan untuk mengetahui Potensi Pasar Tradisional Simabur bagi Masyarakat di Nagari Simabur Kecamatan Pariangan Kabupaten Tanah Datar baik dari segi (1) Lapangan pekerjaan, (2) PendapatanbMasyarakat, (3) Sewa lahan.

Jenis penelitian ini tergolong pada penelitian Deskriptif dengan teknik pengambilan sampel diambil secara Proporsional Random Sampling, dengan jumlah sampel 73 orang, yang menjadi sampel yaitu masyarakat dan pedagang yang berada disekitar pasar Simabur,pengambilan data melalui observasi dan pengamatan langsung ke lapangan dari penyebaran angket.

Penelitian ini menghasilkan beberapa kesimpulan : (1) potensi pasar bagi lapangan pekerjaan masyarakat di Nagari Simabur Kecamatan Pariangan Kabupaten Tanah Datar untuk bekerja, pada umumnya berdagang. (2) potensi pasar bagi pendapatan masyarakat di Nagari Simabur Kecamatan Pariangan Kabupaten Tanah Datar rata-rata masyarakat berpendapatan lebih dari Rp.2.000.000. (3) potensi pasar bagi sewa lahan masyarakat di Nagari Simabur Kecamatan Pariangan Kabupaten Tanah Datar rata-rata sewa lahan perhari Rp.3.000-Rp.6.000.

Kata Kunci: Potensi, Pasar, Masyarakat

\section{PENDAHULUAN}

Pasar adalah tempat dimana terjadi Interaksi antara penjual dan pembeli (Chourmain, 1994: 231). Pasar (market) adalah interaksi antara permintaan (pembeli) dan penawaran (penjual) untuk menentukan tingkat harga barang atau jasa yang diperjualbelikan. (Nurhadi, 2009). Pasar adalah salah satu dari berbagai sistem, institusi, prosedur, hubungan sosial dan instruktur dimana usaha menjual barang, jasa dan tenaga kerja untuk orangorang dengan imbalan uang. Barang dan jasa yang dijual menggunakan alat pembayaran yang sah seperti uang. Kegiatan 
ini merupakan bagian dari perekonomian. Ini adalah pengaturan yang memungkinkan pembeli dan penjual untuk item pertukaran.

Persaingan sangat penting dalam pasar, dan memisahkan pasar dari perdagangan. Pasar bervariasi dalam ukuran, jangkauan, skala geografis, lokasi jenis dan berbagai komunitas manusia, serta jenis barang dan jasa yang diperdagangkan. (Gunadarma, 2011). Pasar tradisional dalah pasar yang dibangun oleh pihak pemerintah, swasta, koperasi, dan swadaya masyarakat tempat usahanya dapat berbentuk toko, kios, los, dan tenda yang menyediakan barangbarang konsumen seharihari masyarakat. Pasar tradisional biasanya dikelola oleh pedagang kecil, menengah, dan koperasi. Proses penjualan dan pembelian dilakukan dengan tawar menawar dan pengelolaannya bermodal kecil (Fattah, 2008).

Pasar tradisional dicirikan dengan terdapatnya hubungan antara pedagang dan pembeli secara langsung. Interaksi antara pedagang dan pembeli terjadi secara spontan, tawar menawar terjadi secara terang-terangan, dan dengan transaksi yang jelas. Ciri ini terdapat pada pasar nagari yang dimiliki oleh nagari-nagari di Sumatera Barat seperti yang tertuang dalam Instruksi Gubernur Kepala Daerah 1 Sumatera Barat No.04 INST 1994 yang isinya tentang Pengelolaan Kekayaan Nagari. Pasar tradisional merupakan tempat bertemunya penjual dan pembeli serta ditandai dengan adanya transaksi penjual pembeli secara langsung dan biasanya ada proses tawarmenawar. Pasar seperti ini masih banyak ditemukan di Indonesia, dan umumnya terletak dekat kawasan perumahan agar memudahkan pembeli untuk mencapai pasar.

Dalam Peraturan Presiden Republik Indonesia Nomor 112 Tahun 2007 tentang penataan dan pembinaan pasar tradisional, pusat perbelanjaan dan toko modern mengatakan bahwa pasar adalah area tempat jual beli dengan jumlah penjual lebih dari satu baik yang disebut sebagai pusat perbelanjaan, pasar tradisional, mall, plaza, pusat perdagangan maupun sebutan lainnya.

Sedangkan yang dimaksud dengan pasar tradisional menurut peraturan tersebut adalah pasar yang dibangun dan dikelola oleh pemerintah, pemerintah daerah, swasta, Badan Usaha Milik Negara, dan Badan Negara Milik Daerah. 
Pasar adalah sisi dunia usaha yang mempunyai karakteristik kerakyatan yang dekat dengan dimensi sosial, ekonomi, dan budaya. Kegiatan di pasar melibatkan masyarakat baik selaku pembeli maupun penjual saling membutuhkan satu sama lainnya. Keberadaan pasar pada hakekatnya bertujuan untuk memberikan pelayanan kepada masyarakat agar bisa memenuhi berbagai keinginan yang dibutuhkan bagi kelangsungan hidup. Masyarakat yang ada sekarang ini pun tidak terlepas dari keberadaan pasar, dimana dengan adanya pasar mereka mempunyai tempat untuk memenuhi kebutuhan rumah tangganya./

Potensi pasar (market potential) adalah ukuran atau nilai total pasar dalam rupiah seandainya semua orang yang memiliki keterkaitan terhadap produk atau jasa yang memiliki daya beli, membeli produk/jasa.

Sewa tanah merupakan konsep penting dalam ekonomi sumber daya tanah. Pada umumnya, orang berpikir bahwa sewa adalah imbalan atau pembayaran yang dibutuhkan untuk penerimaan sebidang lahan atau bangunan pada pemilikinya. Istilah sewa dapat mempunyai arti berikut.

1. Contract Rent; sebagai pembayaran dari penyewa kepada pemilik tanah dan pemilik tanah melakukan kontrak sewa dalam jangka waktu tertentu.

2. Economic Rent atau Land Rent yang merupakan surplus usaha.

Sewa tanah didefinisikan sebagai kelebihan penerimaan dari hasil pemanfaatan tanah yang bersangkutan dengan biaya yang dikeluarkan selain tanah., misalnya tenaga kerja, modal, bahan baku, dan energi yang dipakai untuk mengubah sumber daya alam menjadi barang atau produk. Sewa tanah sebagai surplus ekonomi dapat terjadi karena kesuburannya dan lokasinya.

Pada dasarnya, sewa tanah tersebut merupakan balas jasa untuk pemanfaatan tanah yang dipakai dalam suatu aktifitas. Pasar Simabur merupakan pasar tradisional yang terdapat di nagari Simabur kecamatan Pariangan kabupaten Tanah Datar.Pasar simabur terdiri dari penjual makanan mulai dari buah-buahan dan makanan ringan lainnya, minuman seperti es teler, alat untuk menjahit seperti benang, toko buku dan kaset, warung makanan dan lain-lain. Pasar tradisional menyediakan hampir semua yang dibutuhkan oleh masyarakat seperti sayur, buah, rempah-rempah, alat rumah tangga dan lain sebagainya. 
Masyarakat disekitar menganggapbahwa keberadaan pasar tradisional Simabur sangat membantu dalam memenuhi kebutuhan primer mereka. Karena dengan seiring perkembangan zaman peranan pasar menjadi sangat penting karena melalui pasar kebutuhan seseorang bisa terpenuhi dengan cepat. Perkembangan pasar akan selalu sejalan dengan perkembangan masyarakat. Hasil observasi sementara pasar tradisional simabur memiliki potensi bagi masyarakat yang berada di sekitar pasar sebagai tempat untuk memenuhi kebutuhan sehari-hari, sebagai tempat mencari pekerjaan, meningkatkan pendapatan masyarakat, dan bagi pemilik lahan dapat di sewakan. Berdasarkan pernyataan diatas, penulis tertarik mengetahui lebih dalam tentang "Potensi Pasar Tradisional SimaburBagi Masyarakat Di nagari SimaburKecamatan Pariangan Kabupaten Tanah datar”.

\section{METODOLOGI}

Berdasarkan latar belakang masalah, batasan masalah, rumusan masalah, serta tujuan penelitian maka penelitian tergolong pada penelitian deskriptif. Penelitian deskriptif mengambarkan dan menginterpretasi apa adanya. Sangadji dan Sopiah (2010) mengatakan penelitian deskriptif adalah penelitian terhadap masalah-masalah berupa fakta saat ini dari suatu populasi yang meliputi kegiatan penilaian sikap atau pendapat terhadap individu organisasi, keadaan, ataupun prosedur.

Menurut Cooper,H,M (2007) penelitian deskriptif adalah penelitian yang dilakukan untuk mengetahui nilai variabel atau lebih (indenpenden) tanpa membuat perbandingan, atau menghubungkan dengan variabel lain.

Menurut Sangadji dan Sopiah (2010) populasi adalah wilayah generalisasi yang terdiri atas: subjek dan objek dengan kualitas dan karakteristik tertentu yang di terapkan oleh peneliti untuk dipelajari dan kemudian di tarik kesimpulan .

Untuk memperoleh jawaban tentang bagaimana potensi pasar tradisional bagi masyarakat di nagari Simabur kecamatan Pariangan Kabupaten Tanah Datar, yang menjadi populasi dalam penelitian ini adalah masyarakat yang terdapat di sekitar kengarian Simabur itu sendiri.. 


\section{PEMBAHASAN}

Berdasarkan hasil penelitian yang dilakukan di kenagarian Simabur Kecamatan Pariangan Kabupaten Tanah Datar di atas maka dengan itu di bahas tentang : 1) potensi pasar tradisional Simabur bagi lapangan pekerjaan masyarakat Nagari Simabur, 2) potensi pasar tradisional Simabur bagi pendapatan masyarakat Nagari Simabur, 3) potensi pasar tradisional simabur bagi sewa lahan masyarakat Nagari Simabur.

Potensi pasar tradisional Simabur bagi lapangan pekerjaan masyarakat di Nagari Simabur Kecamatan Pariangan Kabupaten Tanah Datar menunjukkan potensi pasar bagi lapangan pekerjaan masyarakat untuk bekerja, rata-rata peluang kerja masyarakat berpeluang tinggi, dengan adanya potensi pasar bagi lapangan pekerjaan masyarakat, masyarakat dapat bekerja sebagai pedagang, ojek, kebersihan dan tukang parkir. Sehingga dapat mengurangi pengangguran.

Hal ini sesuai yang dikatakan Lewis, dalam Todaro (1985: 66). Lapangan pekerjaan adalah bidang kegiatan dari pekerjaan/ usaha / perusahaan / kantor dimana seseorang bekerja. Ketenagakerjaan, yaitu kelebihan pekerja merupakan kesempatan dan bukan masalah. Potensi pasar tradisional Simabur bagi lapangan pekerjaan masyarakat di Nagari Simabur Kecamatan Pariangan Kabupaten Tanah Datar menunjukkan potensi pasar bagi lapangan pekerjaan masyarakat untuk bekerja, rata-rata masyarakat dapat bekerja sebagai pedagang.

Potensi pasar tradisional Simabur bagi pendapatan masyarakat di Nagari Simabur Kecamatan Pariangan Kabupaten Tanah Datar menunjukkan potensi pasar bagi pendapatan masyarakat dengan adanya pasar, pendapatan dengan adanya pasar rata-rata sangat cukup, sehingga dapat membantu perekonomian masyarakat, memenuhi kebutuhan sehari-hari, dan membantu pendapatan masyarakat.

Hal ini sesuai yang dikatakan Dyckman (2002;234). Pendapatan adalah “arus masuk atau peningkatan lainya atas aktiva sebuah entitas atau penyelesaian kewajiaban (atau kombinasi dari keduanya) selama satu periode dari pengiriman atau produksi barang, penyedian jasa, atau aktivitas lainya yang merupakan operasi utama atau sentral entitas yang sedang berlangsung”. Potensi pasar 
tradisional Simabur bagi pendapatan masyarakat di Nagari Simabur Kecamatan Pariangan Kabupaten Tanah Datar menunjukkan potensi pasar bagi pendapatan masyarakat dengan adanya pasar, pendapatan dengan adanya pasar rata-rata sangat cukup, sehingga dapat membantu perekonomian masyarakat.

Potensi pasar tradisional bagi sewa lahan masyarakat di Nagari Simabur Kecamatan Pariangan Kabupaten Tanah Datar, dengan demikian mayarakat yang berada di sekitar pasar Simabur dapat memanfaatkan lahan yang ada untuk disewakan, dan menyewakan lahan kepada pedagang untuk mendapatkan uang sebagai pendapatan tambahan.

Hal ini sesuai yang dikatakan Von thunen (1826). Sewa tanah didefinisikan sebagai kelebihan penerimaan dari hasil pemanfaatan tanah yang bersangkutan dengan biaya yang dikeluarkan selain tanah, misalnya tenaga kerja, modal, bahan baku, dan energi yang dipakai untuk mengubah sumber daya alam menjadi barang atau produk. Potensi pasar tradisional bagi sewa lahan masyarakat di Nagari Simabur Kecamatan Pariangan Kabupaten Tanah Datar, dengan demikian masyarakat yang berada di sekitar pasar Simabur dapat memanfaatkan lahan yang ada untuk disewakan, dan menapatakan uang sebagai gantinya sehingga dapat menambah pendapatan dari hasil sewa lahan tersebut.

\section{KESIMPULAN}

Berdasarkan uraian pada deskripsi data dan pembahasan data di atas dapat diambil kesimpulan bahwa:

1. Potensi pasar tradisional Simabur bagi lapangan pekerjaan masyarakat di Nagari Simabur Kecamatan Pariangan Kabupaten Tanah Datar menunjukkan potensi pasar bagi lapangan pekerjaan masyarakat untuk bekerja, rata-rata masyarakat berdagang.

2. Potensi pasar tradisional Simabur bagi pendapatan masyarakat di Nagari Simabur Kecamatan Pariangan Kabupaten Tanah Datar menunjukkan potensi pasar bagi pendapatan masyarakat dengan adanya pasar, bekerja lebih dari 3 jam sehari dengan pendapatan memenuhi rata-rata lebih dari Rp.2.000.000.

3. Potensi pasar tradisional bagi sewa lahan masyarakat di Nagari Simabur Kecamatan Pariangan Kabupaten Tanah Datar menunjukkan bahwa potensi 
pasar bagi sewa lahan masyarakat di pasar Simabur perhari rata-rata Rp.3.000Rp.6.000.

\section{DAFTAR PUSTAKA}

Asikin, Zainal, Amirudin, 2012, Pengantar Metode Penelitian Hukum, Jakarta: Raja Grafindo Persada.

http://www.yipd.or.id/files/Best_Practice/perbaikan_usaha_mikro_kredit.pdf. Di Akses 10 Desember 2015.

http://www.kajianpustaka.com/2013/10/potensi-diri.html. Di Akses 10 Desember 2015.

Kasmir. 2006. Kewirausahaan. Jakarta : Raja Grafindo Persada

K. Wardiyatmoko. 2009. Ilmu Pengetahuan Sosial SMP KELAS VIII. Jakarta : Erlangga.

Masitoh. 2013. Upaya Menjaga Eksistensi Pasar Tradisional: Studi Revitalisasi Pasar Piyungan Bantul. Pdf. Di Akses 10 Desember 2015.

Santoso, Umilia \& Aulia. 2012. Diktat Analisis Lokasi dan Keruangan (RP091209). Institut Teknologi 10 nopember Surabaya.

Sherraden, Michael. 2006. Aset Untuk Orang Miskin. Jakarta: Raja Grafindo

Sudarmadi. 2008. Pemberdayaan Kelompok Ekonomi Produktif Sidodadi Oleh Karang Taruna Desa Srimartani Puyungan Bantul. (Skripsi). Yogyakarta: Universitas Sunan Kalijaga.

Sumargo. 2002. Perkembangan Teori Sewa Tanah Dalam Perspektif Pemikiran Ekonomi. Pdf. Di Akses 10 desember 2015

Sutami. 2005. Strategi Rasional Pedagang Pasar Tradisional. Pdf. Di Akses 10 Desember 2015 .

Zunaidi. 2013. Kehidupan Sosial Ekonomi Pedagang Di Pasar Tradisional Pasca Relokasi Dan Pembangunan Pasar Modern. Pdf. Di Akses 10 Desember 2015. 